Pedagogy: Journal of English Language Teaching

Volume 9, Number 2, December 2021

E-ISSN: 2580-1473 \&P-ISSN: 2338-882X

Published by Institut Agama Islam Negeri Metro

\title{
Parents' Perception of Parenting Education of Language Politeness
}

\author{
Chubbi Millatina Rokhuma1 ${ }^{*}$, Eros Meilina Sofa ${ }^{2}$, Rayinda Eva Rahmah ${ }^{3}$ \\ Institut Agama Islam Negeri (IAIN) Pekalongan, Indonesia ${ }^{1,2,3}$ \\ Email: chubbi_millatina@iainpekalongan.ac.id ${ }^{1^{*}}$
}

ARTICLE INFO

Article history:

Received

April 25th, 2021

Revised

September 2nd, 2021

Accepted

November $11^{\text {th }}, 2021$

\begin{abstract}
This paper aims to explore the parental perception of parenting education of language politeness held in the village hall of Kwasen, one of villages in the sub-district of Kesesi, Pekalongan regency. Qualitative interviews were conducted with five parents of children aged 4-10 years, following the seminar. The finding showed that most of them get new knowledge about how to educate their children about language politeness, especially in familiarizing the use of magic words including: thank you, please, excuse me, as well as sorry in daily communication. In conclusion, following parenting education, especially in the case of language politeness can be said as a necessary for parents. Therefore, this study contributes to provide some ways that can help parents in introducing polite speech acts including magic words to their children in their daily communications.
\end{abstract}

Keywords: parents; parenting education; children; linguistic politeness; magic words.

How to cite

Rokhuma, C. M., Sofa, E.M., Rahmah, R.E., (2021). Parents' Perception of Parenting Education of Language Politeness. Pedagogy: Journal of English Language Teaching, 9(2). 177-188

DOI 10.32332/joelt.v9i2.3573.

Journal Homepage https://e-journal.metrouniv.ac.id/index.php/pedagogy

This is an open access article under the CC BY SA licensehttps://creativecommons.org/licenses/by-sa/4.0/

\section{INTRODUCTION}

Politeness is a topic that people have various different opinions, including both linguistic scholars and researchers who also have distinctive views. Politeness refers to a deeper phenomenon, something that human communicators would find it hard to do without (Leech, 2014). Politeness is also a living manifestation found very generally in human languages of human society within the human cultures. Hence, politeness has to be studied in terms of how to be polite. Leech also suggests that being polite means 
people speak as well as or behave in such a way as to give benefit or value not to yourself but to other people, especially the person(s) you are conversing with(Leech, 2014). Being polite to others means that you respect them and try to create a comfortable situation in communications (Percival \& Pulford, 2019). Having a polite attitude is practicing social relationships by regarding appropriateness, ethics, and moral values that develop in the society. This fact enables politeness to be taught since elementary level (Muammar, Suhardi, \& Mustadi, 2019). This reminds us that as humans, we are required to show being polite and to say polite words generally to society. In society, politeness practice sometimes becomes a measurement of whether someone has good or bad behavior. Children have been taught how to act politely will perform differently those who have not.

At the same time, although many linguistic scholars and researchers have seen that the terms of politeness become a good thing as an essential part the socialization process, in some situations, the impoliteness cannot also be ignored which is often found and showed by bad words or improper behaviors in some people. As stated by Sifianou (2010) that "impoliteness is behavior that is faceaggravating in a particular context". Impolite attitude performed by children is closely recognized as bad behavior and as if they do not respect others.
One of important parts of politeness is linguistic politeness. Linguistic politeness in language formulation used to create a positive atmosphere among people involved in communication as a means to prevent Disputes (Chapman \& Routledge, 2009). The development of the language in children is primarily reflected by the socio-cultural environment around them because they are considered involving in the communication and interaction with other people as Brown \& Levinson (1988) said politeness phenomena are very nature reflected in language in addition to the status as universal principles of human interaction. Almost every day in the daily routines, children do not only play, but also interact with other children and society. As in fact, many Indonesian Children, especially in Java, can actively acquire their native language, that is Javanese, which they start to naturally produce the utterance as they are growing up. Besides, when they are in school, the mother language, Bahasa, and the foreign language, English, also need to be studied and performed appropriately as they are learning these two languages of the school subjects. Soon, the children would find and understand the flow of the language use leading into their verbal repertoire both in a form of politeness and impoliteness.

The issues of politeness should be taught to children because they tend to have and get the benefit if they can demonstrate well and show being polite. 
Demonstrating language politeness is in the form of routine politeness that is implemented in the children's interaction. Politeness is universally used and remains in social life, but it doesn't mean that routine politeness is not important (Gleason, Perlmann, \& Greif, 1984). One of the indicators performed by the children is the use of magic words (please, excuse me, thank you, sorry). It is possible if the children soon discover that saying polite ways such as thank you as the best, and most polite response to a compliment is a simple way like when other people giving them a gift or a present. Another thing dealing with showing politeness is when children learn to apologize. An apology made to other friends perhaps could be shown by simply saying I' $m$ sorry in a tone that sounds somewhat sincere (Berkenkamp \& Atkins, 2001). Hence, the importance of asking children to say things like please and thank you, which are insisted on by their parents in the process of socialization - becoming "paid-up" members of human society (Leech, 2014). Therefore, the parents play the role of directly teaching their children to use polite words and also the function of language in social interaction in general, and more specifically, as a context for learning stylistic variation (Gleason et al., 1984).

Much new research identifies the powerful ways parents contribute to children's positive growth and development in big and small ways
(Brooks, 2011). The power of a positive relationship between parents and children built in the process of parenting. According to Rothe et al. (2016), parenting is a process of action and interaction between parent and child; it is a process in which both parties change each other as children grow to adulthood. To support the parenting process, parents are suggested to follow the parent education programs. In Indonesia, the programs that are wildly offered mainly by the government, parenting community, or even the private associations are supposed to help parents to gain the benefits and best practices around parenting education. The following summarizes the positive outcomes from the Wilder Research in how the parenting education program can provide and help the children and also families: (1) Improving parental empowerment and self-confidence as well as competency in caregiving; (2) Increasing positive parenting practices; (3) Increasing social connections; (4) Improving child behavior; (5) Improving parent-child interactions; (6) Improving parental mental health and well-being; (7) Decreasing use of corporal punishment and risk of child abuse(Rothe, Rogers, \& Maggie, 2016)

Related to the parenting program, it is undeniable that the parents' perception also takes role in children's education. There are several factors which affect the perception, including age, gender, income, occupation, education, language, and psychographic (Bhutto). 
A large number of studies have been concerned with parenting education. Most of them have looked at parenting education which deals with children's school achievement and also have focused on the strategies in optimizing the parents' participation to carry out the interaction with children. A study from Nuzula et al. (2017) found that parenting education has significant effect toward independency and emotional regulation skill to pre school. Likewise, Amini (2017) who implemented various parenting education programs and styles in Kindergarten, concluded that the programs could meet the needs and solutions of children's problems either at school or at home. A similar result also found by Bibi et al. (2013), which concluded that parenting education styles could positively influence the psychological mentally healthy children.

The studies presented above allows us to draw that majority of studies are more likely to prefer parenting education in the context of knowing the achievement of children at school and the general effects of conducting parenting education programs. Therefore, we need to gain more insights the parenting education which focuses on children's language, particularly to notice the use of politeness words when interacting to other people. Therefore, this study aims to offer a parenting education programs for parents and to explore perception which deals with the linguistic politeness, especially in familiarizing the magic words for their children held in the Kwasen, one of villages in the Sub-disctrict of Kesesi, Pekalongan regency.

\section{METHOD}

To explore the detailed information of the issue, this study was conducted through qualitative approach by using case study. By using case study, the phenomenon can be explored deeply to provide quality description of the research problems (Creswell, 2014). Meanwhile, according to LeCompte \& Schensul (2010), a case study allows the researchers to assess and describe what is happening after all as what is happening over time. Furthermore, the researchers can capture and enlighten narration of the participants' perspectives and experiences. Thus, in this case, the use of case study helped to explore parents' perception of parenting education of language politeness held on $10^{\text {th }}$ July 2020 in the village hall of Kwasen, one of villages in the sub-district of Kesesi, Pekalongan regency. This location was chosen because it was the first parenting education held in that village held by some lecturers of IAIN Pekalongan with Ningsih Fadhilah, a counseling lecturer, as the keynote speaker. Furthermore, it is also the first experience for the participants to follow such program. Therefore, in this case, the researchers are curious and want to know how was the participants' 
perception after following the parenting education.

Overall, this study was conducted in some steps; planning, conducting, and reporting. In the planning step, the researchers prepared the amount of the interviewees, the interview guideline, as well as related literature needed for the documentation. After that, the researchers collected some information from the respondents through interview. In this case, the data were collected from the five participants of the parenting education seminar. At last, the researchers reported the result of the study. It was conducted by analyzing the gathered data from the respondents and followed by conclusion drawing.

In gaining the data, the technique of interview and documentation were used in this research. The interview technique was used to gain the data related to the parents' perception of parenting education, while the documentation technique was used to collect related references on parenting education and language politeness. The design of the instrument was adapted from NASEM (2016) and Wilder Research's (2016) concept about the benefit of parenting education (as cited in Child welfare, 2019).

The data collection was started by having an interview. Five participants following the parenting education, especially parents of children aged $4-10$ years were chosen to be interviewed. The interview was conducted by using home visit technique and using the Javanese language as well as Bahasa Indonesia to assist the participants in delivering their message.

Moreover, the researchers transcribed the taped interviews with five participants into transcriptions to get the collected data which then were analyzed by using interactive model of Miles \&Huberman (1994). The steps include data reduction, data display, and verification/conclusion drawing. In the step of data reduction, the collected data were chosen based on the main point of the research problem. In the data display, the data were provided in the form of interview transcriptions as well as a broader description as the result of the theory analysis. Finally, the conclusion drawing was conducted by concluding the most common answer of the participants and the contribution of this study.

\section{RESULTS AND DISCUSSION \\ Children's Language Politeness}

To measure language politeness practiced by children in Kwasen, this study used magic words in three languages (Indonesian, Javanese, and English). Reasons for choosing those three languages are:

1. Indonesian is a language that the children use in their school, and it is our national language that must be mastered by Indonesian people.

2. Javanese is the first language in that village. The children are more familiar 
in using that language rather than others.

3. English is one of the subject in the children's school. They have learned some vocabulary and terms related to their surrounding.

Those magic words are very common words, which show someone's attitude and politeness. The more they use those words, the more they know what politeness is. Those words are:

\begin{tabular}{ccc}
\hline Indonesian & Javanese & English \\
\hline Terimakasih & Maturnuwun & Thank you \\
Maaf & Ngapunten & Sorry \\
Tolong & Nyuwuntulung & Please \\
Permisi & Nuwunsewu & Excuse me \\
\hline
\end{tabular}

Terimakasih/Maturnuwun/Thank you is part of gratitude. It is closely related to life satisfaction, happiness, optimism, hope, and positive affect (McCullough, Emmons, \& Tsang, 2002). It is a part of politeness shown by people in daily communication. Being polite means they do not think too much to say thank you to other people, not only to show their respect but also to appreciate others.

Maaf/Ngapunten/Sorry, as part of apologizing, provides benefits for the people in communication. When we apologize, it is beneficial in resolving conflict, reducing feelings of aggression, and fostering forgiveness(Fehr, 2007).Tulung/Tolong/Please is one of the part of being polite in the form of asking requests, both for something or help.
Along with "thank you", this word refers to formal politeness which most people recognize as polite in daily communication (Mills, 2003). Nuwunsewu/permisi/excuse me is the expression of asking permission. It shows that we ask for permission for use other's things or do something which gives effect to others. By saying this word, we respect realize others' existence and respect them. Therefore, this word needs to be emphasized to children from the beginning.

Regarding the use of magic words, it is closely related to the communication pattern that they face every day. Children in Kwasen often use "Terimakasih" (thank you). It is more common in use in their daily communications. This case is influenced by their communication role, meaning that their daily communication is dominated by the use of gratitude instead of other expressions. Many conditions stimulate the children to use this expression, such as receiving something from others, getting help/assistant, getting permission, and other conditions.

Meanwhile, other magic words such as Maaf, Permisi, Tolong (sorry, excuse me, please) are rarely practiced by the children. The parents had introduced their children to say"maaf" (sorry) when they did a mistake or when they argued with their friends. However, the use of this expression is not too familiar for children because not all children realize they have made a mistake. "Permisi" (excuse me) has also been introduced to the children by 
their parents when the children need to walk among older people. But actually, this situation is rarely faced by the children in their daily life, and sometimes because they are not alone, they believe that they do not have to say that word. Along with the other expressions, "tolong" (please) is also taught to the children when they need help from others, although this situation rarely happens in their life.

On the other hand, not all children of Kwasen use Bahasa in their daily communications. Most of the mareused to communicate in Javanese. Even, their parents taught them to communicate in Javanese. It is not a big deal, actually, as far as they still use polite words in performing the Javanese language.

Unfortunately, most of the children choose to use ngoko instead of kromo when they talked to their parents. Ngoko is the form of Javanese language which normally used to talk with peer, or from the older to the younger people. While based on Javanese language ethics, children have to use kromowhen they speak to their parents or other older people. The parents said that their children use ngoko to communicate with the elderly does not mean that they do not respect the older people. It happens because the children listen to ngoko more often than kromo in their daily communication.

Actually, on one side, this situation and ethics did not become a serious problem for the parents because they tended to neglect the importance of
Javanese kromo used by children. But, on the other sides, parents still had big hope for their children to be honored people in the future. They still emphasize that kromo is still the priority when they are communicating with the older people to show their respect.

\section{Parents' Perception of Parenting Education}

Parenting education is one of the expected and needed activities by parents, especially mothers in Kwasen village. This kind of education minimizes the risk of child abuse and neglect by encouraging positive parenting practices that promote safety, well-being, and permanency for children and families (www.childwelfare.gov). This program does not mean to be the only teaching and modeling facility for the parents to teach and take care of their children.It also provided the room for sharing and consulting eachother for the parents, enabling them to feel that they were not alone in facing those problems. While parenting may come naturally to some, others may need additional support and guidance to understand child development, to respond appropriately to their child's needs, and to cope with the challenges of parenting.

This parenting education was held in Kwasen to educate the parents in taking care of their kids. The Parenting education program was held for about three hours inviting parents of children in elementary 
school and kindergarten levels. This program also invited a practitioner of politeness as a speaker, who is also a lecturer in Pekalongan. Focus of this program was reminding the parents of the importance of habituating politeness for their children as well as finding the solution faced by the parents in habituating politeness for their children. Most of the parents were very enthusiastic in attending and participating in that program because they felt that politeness in one of important thing that must be highlighted since childhood. This event got tremendous responses from the mothers as the participants. Although this event was held during this pandemic considering the rule of health protocol, most of the participants were still enthusiastic to gain new insight. Even, at the end of this activity, most participants expected there would be a next session to reach more participants and to share more material.

Regarding the parents' response to the activity, this study investigated their perception after following the education.Parents' perception plays vital role in children's education in terms of performance and career choice. Numerous factors shape parents perception regarding children's education which ultimately influences the children attitude towards education. Parents with different demographic and psychographic characteristics have different expectations for the education of their children.
Understanding parents' perceptions about parenting education may help this study understand the weaknesses and strengths of the education. So that government and other parties in the village may more effectively promote the kind of education(Erdener \& Knoeppel, 2018).

Based on the interview result, it was found that the parents welcome to the parenting education program. They had not joined such an event before, and it was their first parenting education. They said that the event was very beneficial. They got new knowledge they have ever got about taking care and teaching their children in habituating linguistic politeness. Some of the participants said that they had not known how to habituate politeness to their children and create a polite atmosphere for their children at home. They also ignore that being a model for their children is the most important thing to do in educating their children. As Jum said "jane niku nekwonten acara ngoten, kados dielikke niko si, dadine ngertos....o...nggih...ngoten." She said that by following parenting program, especially in linguistics politeness, she can tech her children about how to speak politely. She is also able to let her children know about how to habituate magic words including thanking, apologizing, asking for permission, as well as asking for help in a proper way. It is in line with Viola, Coleman, Glennon, \& Pastorek (2020) stating that parenting education is aimed to develop knowledge and skills of the 
parents. By following the event, the parents know how to deliver linguistic politeness properly. The information they got in that program has opened their mind to the case of the right way in teaching linguistic politeness for children.

Besides, one of the parents also said that after joining the event, they know what to do relate to how to have good communication with their children. This fact is following Wilder Research (Rothe et al., 2016) that following parenting education can help parents to create better quality parent-child interactions as a result of parents learning how to engage with their children. Some parents realized that delivering something including suggestions, advice, as well as new information or knowledge to their children is not always easy. Sometimes they have such a debate in its process. This condition is often faced by many parents because they do not really understand how to have a proper communication with their children. It even often causes disputes between children and parents. After joining the parenting program, some parents admit that they were happy for becoming part of the participants in that program. They said that they could have good communication in delivering new information as well as giving some advice to their children. This fact is following Wilder Research (Rothe et al., 2016) that following parenting education can help parents to create better quality parentchild interactions as a result of parents learning how to engage with their children. As a result, parenting education can bring positive influence in the case of behavior of both parents and children as well as make better quality of interaction. The information obtained from the parenting program has helped some parents in creating a better atmosphere between children and parents. This condition, of course, could also make those parents easier in habituating magic words including thanking, apologizing, asking permission, as well as asking for help in a proper way.

Another fact found from holding the interview is that by having a speaker and other participants in one discussion forum, the parents could share their experiences and difficulties in teaching their children about politeness, as well as find the solution. The discussion forum was intended to serve the parents by providing some insightful things shared by the speaker. In addition to the event of the discussion forum, there was also a sharing information session which aided to more get engaged between the speaker and the parents. In this session, many problems appeared and were shared by some parents in dealing with for example, how to have a proper communication with their children at home. During this session, parents as the audience were excited to follow. It could be seen from their responses after joining this event. Many of them have believed that sharing information with the speaker who is 
capable of the practical things of doing parenting and also with other parents could help them know how to solve their family problems related to taking care of their children based on the real situation. This fact is in line with aggregate Parent Skills Ladder (PSL) data from OPEC 2018 showing that there is improvement of parents communicating with other parents to share their experiences after joining parent education. In this case, it means that by joining parent education, parents can share their experience including their difficulties in habituating linguistic politeness such as the use of magic words "thank you, sorry, excuse me, as well as please" in their daily communications.

\section{CONCLUSION}

The study came into a conclusion that parenting education especially in the case of linguistic politeness becomes an interesting thing for parents. It could be seen from the finding that showed the parenting education of linguistic politeness held in one of the villages in Pekalongan regency has successfully contributed to help the parents. Some of them are now aware of the importance of familiarizing magic words to their children in daily communication because they get new knowledge, particularly about how to educate their children towards the use of language politeness in daily communication. The result of this study contributes to provide new insights in which delivering polite speech act including magic words to children can be well carried out when the parents know the ways, and parenting education can facilitate parents to know the best ways in delivering polite speech act to children. Furthermore, it also contributes to encouraging the local government to routinely hold such kind of parenting education as a guide for parents in bringing up their children. Moreover, the result of this research is also supposed to be able to make the parents inspired in following any parenting education either online or offline.

\section{ACKNOWLEDGEMENT}

The researchers would like to express their gratitude to those involved in this study.

\section{AUTHOR CONTRIBUTION STATEMENT}

$\mathrm{CM}$, EM, and RE conceived the presented idea. With the support from EM and RE, CM collected and analyzed the data, as well as wrote the manuscript.

\section{REFERENCES}

Amini, M., \& Info, A. (2017). Implementation of Parenting Education Program in Kindergarten. Indonesian Journal of Early Childhood Education Studies, 6(2), 108-114. https://doi.org/10.15294/ijeces.v6i 2.20240 
Berkenkamp, L., \& Atkins, S. C. (2001). TEACHING YOUR CHILDREN GOOD MANNERS a Go Parents! guide. Saudi Med J (Vol. 33). Nomad Press.

Brooks, J. B. (2011). The Process of Parenting (8th ed.). New York: McGraw-Hill Companies.

Brown, P., \& Levinson, S. C. (1988). Politeness: Some Universals in Language Usage. TESOL Quarterly (Vol. 22). Cambridge: Cambridge University Press. https://doi.org/10.2307/3587263

Chapman, S., \& Routledge, C. (2009). Key Ideas in Linguistics and the Philosophy of Language. Key Ideas in Linguistics and the Philosophy of Language. Edinburgh University Press. https://doi.org/10.5860/choice.470018

Creswell, J. W. (2014). Research Design: Qualitative, Quantitative, and Mixed Method Approaches (4th ed.). SAGE Publication

Erdener, M. A., \& Knoeppel, R. C. (2018). Parents' perceptions of their involvement in schooling. International Journal of Research in Education and Science, 4(1), 1-13. https://doi.org/10.21890/ijres.3691 97

Farzana Bibi, F. B. (2013). Contribution of
Parenting Style in life domain of Children. IOSR Journal of Humanities and Social Science, 12(2), 91-95. https://doi.org/10.9790/08371229195

Fehr, R. (2007). When Apologies Work: The Benefits of Matching Apology Content to Victims and Context. University of Maryland.

Gleason, J. B., Perlmann, R. Y., \& Greif, E. B. (1984). What's the Magic Word: Learning Language through Politeness Routines. Discourse Processes, 7(4), 493-502. https://doi.org/10.1080/016385384 09544603

LeCompte, M. D. \& Schensul, J. J. (2010). Designing \& Conducting Ethnographic Research (2nd ed.). Plymouth: AltaMira Press.

Leech, G. (2014). The pragmatics of Politeness. Oxford University Press. New York: Oxford University Press. https://doi.org/10.4324/978131585 7381

McCullough, M. E., Emmons, R. A., \& Tsang, J. A. (2002). The grateful disposition: A conceptual and empirical topography. Journal of Personality and Social Psychology, 82(1), 112-127. https://doi.org/10.1037/00223514.82.1.112 
Mills, S. (2003). Gender and Politeness. (P. Drew, M. H. Goodwin, J. J. Gumperz, \& D. Schiffrin, Eds.). Cambridge: Cambridge University Press.

Muammar, Suhardi, \& Mustadi, A. (2019). Language Politeness Use of Viola, S. B., Coleman, S. L., Glennon, S., \& Elementary School Students in Mataram. In 3rd International Conference on Current Issues in Education (ICCIE 2018) (Vol. 326, pp. 337-343). Atlantis Press.

Nuzula, F. Dwiyanti, R. Raraningrum, V. (2017). Effectiveness of Parenting Education Towards Parents Role in Growth and Development of Pre School Children, 196-201.

Percival, N. M., \& Pulford, B. D. (2019). Do say "thank you": Verbal expressions of politeness and gratitude influence interpersonal perceptions. Journal of General Psychology, 147(3), 228-243.

https://doi.org/10.1080/00221309.2 019.1690970

Rothe, M. C., Rogers, S. T., \& Maggie, S. (2016). The Benefits of Parenting Education: A Literature Review for the Wilder Parent Education Center (Vol. 12). Minnesota. theory and practice. Berlin \& New York: Mouton de Gruyter, 2008. Pp viii, 346. $\mathrm{Hb} \$ 125.00$. Language in Society, 39(1), 119-131. https://doi.org/10.1017/s00474045 09990674 Pastorek, M. E. (2020). Use of parent education to improve self-efficacy in parents of students with emotional and behavioral disorders. Evaluation and Program Planning, 82(April 2019), 101830. https://doi.org/10.1016/j.evalprog plan.2020.101830

Sifianou, M. (2010). Derek Bousfield \& Miriam A. Locher (eds.), Impoliteness in language: Studies on its interplay with power in 